\title{
Correction to: Functional and clinical significance of ROR1 in lung adenocarcinoma
}

\author{
Giovanna Schiavone ${ }^{1 * \dagger}$, Samantha Epistolio ${ }^{2 \dagger}$, Vittoria Martin ${ }^{2}$, Francesca Molinari ${ }^{2}$, Jessica Barizzi ${ }^{2}$, \\ Luca Mazzucchelli ${ }^{2}$, Milo Frattini ${ }^{2+}$ and Luciano Wannesson ${ }^{1+}$
}

\section{Correction to: BMC Cancer 20, 1085 (2020) https://doi.org/10.1186/s12885-020-07587-6}

Following publication of the original article [1], the authors reported that the family names and the given names of the authors were interchanged. The names published in this correction article have been corrected and are as follows:

Giovanna Schiavone (given name, family name)

Samantha Epistolio

Vittoria Martin

Francesca Molinari

Jessica Barizzi

Luca Mazzucchelli

Milo Frattini

Luciano Wannesson

The original article [1] has been corrected.

\section{Author details}

${ }^{1}$ Istituto Oncologico della Svizzera Italiana, Via Ospedale, 6500 Bellinzona, Switzerland. ${ }^{2}$ Istituto Cantonale di Patologia, Via in Selva 24, 6600 Locarno, Switzerland.

Published online: 07 December 2020

\section{Reference}

1. Schiavone G, Epistolio S, Martin V, et al. Functional and clinical significance of ROR1 in lung adenocarcinoma. BMC Cancer. 2020;20:1085. https://doi. org/10.1186/s12885-020-07587-6.

The original article can be found online at https://doi.org/10.1186/s12885020-07587-6.

*Correspondence: giovanna.schiavone@eoc.ch

${ }^{\dagger}$ Giovanna Schiavone and Samantha Epistolio are co-first authors

${ }^{\dagger}$ Milo Frattini and Luciano Wannesson are co-senior authors

'Istituto Oncologico della Svizzera Italiana, Via Ospedale, 6500 Bellinzona, Switzerland

Full list of author information is available at the end of the article

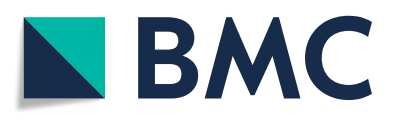

(c) The Author(s). 2020 Open Access This article is licensed under a Creative Commons Attribution 4.0 International License, which permits use, sharing, adaptation, distribution and reproduction in any medium or format, as long as you give appropriate credit to the original author(s) and the source, provide a link to the Creative Commons licence, and indicate if changes were made. The images or other third party material in this article are included in the article's Creative Commons licence, unless indicated otherwise in a credit line to the material. If material is not included in the article's Creative Commons licence and your intended use is not permitted by statutory regulation or exceeds the permitted use, you will need to obtain permission directly from the copyright holder. To view a copy of this licence, visit http://creativecommons.org/licenses/by/4.0/ The Creative Commons Public Domain Dedication waiver (http://creativecommons.org/publicdomain/zero/1.0/) applies to the data made available in this article, unless otherwise stated in a credit line to the data. 